\title{
Evaluation of Tomato Genetic Resources for Response to Water Deficit
}

\author{
Adriana Sacco, Barbara Greco, Antonio Di Matteo, Rosalba De Stefano, Amalia Barone* \\ Department of Agricultural Sciences, University of Naples Federico II, Portici, Italy. \\ Email: *ambarone@unina.it
}

Received November $25^{\text {th }}, 2013$; revised December $24^{\text {th }}, 2013$; accepted December $31^{\text {st }}, 2013$

Copyright (C) 2013 Adriana Sacco et al. This is an open access article distributed under the Creative Commons Attribution License, which permits unrestricted use, distribution, and reproduction in any medium, provided the original work is properly cited.

\begin{abstract}
Water deficit strongly affects plant yield and quality. However, plants can minimize drought injury by adaptation mechanisms that have evolved to escape harmful conditions. The response to water deprivation is a complex trait controlled by several genes. In order to gain a deeper understanding of drought response mechanisms in tomato, a collection of 27 genotypes was studied under different water deficit conditions. Since developmental stages might be differently influenced by drought, analyses were carried out on young plantlets during fruit setting. The only genotype that showed good performances both as water retention and fruit production was the ecotype Siccagno. All the genotypes were analyzed at molecular level with the aim of detecting structural polymorphisms in selected stress-responsive genes. In addition, the expression level of a number of these genes was measured in the genotypes more tolerant to water deficit. Many polymorphisms were detected in six stress-responsive genes, and some could imply significant modifications in the protein structure. Furthermore, the expression analysis by RT-qPCR of three stress-responsive genes allowed arguing that a higher level of expression of the gene erd15 might be related to the better response to water deficit exhibited by Siccagno. Similarly, the lower expression of eight genes in the same genotype analysed through a microarray experiment confirmed the involvement of these stress-related genes in the tomato response to drought. Further investigations are required for a better comprehension of the mechanisms underlying response to water deficit in tomato by exploiting the genetic resource identified as more tolerant. The use of new technologies able to globally analyze structural polymorphism and expression level of genes will succeed to identify crucial genes involved in stress response in the ecotype Siccagno grown under different water regimes.
\end{abstract}

Keywords: Drought-Tolerance; Water Loss Rate; Relative Water Content; Yield Evaluation; Gene Polymorphisms

\section{Introduction}

Water deficiency is one of major environmental constraints that strongly affect cultivated plants, reducing growth and yield. However, plants can minimize drought injury by adaptation mechanisms that have evolved to escape harmful conditions [1]. The drought tolerance mechanism is a polygenic trait controlled by several small effect genes or QTLs and leads to physiological, biochemical and molecular changes, such as the synthesis of abscisic acid (ABA), the accumulation of various osmolytes and proteins with a role in repair and protection in synergy with an efficient antioxidant system [2]. The physiological mechanisms that allow plants to overcome the stress condition and to grow during episodes of stress have been extensively studied [3]. They include

"Corresponding author. maintaining cell turgor pressure and reducing water loss by the accumulation of molecules such as betaine, proline, sorbitol, and so on [4]. As for physiological and biochemical mechanisms, many drought-related genes with different roles have also been identified through molecular and genomic analysis of Arabidopsis, rice, tomato and other species [5-7]. The large-scale analysis of the transcriptome has demonstrated the presence of hundreds of genes that are activated or repressed in response to osmotic and water stress $[8,9]$. To address the complexity of plant responses to drought, it is vital to understand the physiological and genetic basis of this response [10].

Despite significant progress during the past decade in our understanding of pathways affected by drought stress, limited information is available regarding the dynamic of gene networks in tomato under stress conditions. Com- 
pared to other tomato abiotic stresses, less mapping research has been conducted on tomato drought tolerance [11]. In effect, in the past years, breeding efforts to improve drought tolerance have been hindered by its quantitative genetic control and by the poor understanding of the physiological basis of yield in water-limited conditions [12].

Nowadays, thanks to the completed sequencing of tomato genome [13], dozens of genes important for tomato breeding have been mapped and molecular markers are available online (http://sgn.cornell.edu). Knowing the candidate genes for important traits and the exact functional nucleotide polymorphism within these genes, breeders can identify useful alleles in the available germplasm. In addition, breeders can create novel genotypes through the introgression/pyramiding of favourite unused natural alleles and/or by shuffling and re-organizing genomic sequences. In addition, plant breeders can consider manipulating transcription and regulation factors to generate a pool of new trait variations.

Our goal was to study the effects of water deficit on the tomato plant, both at level of plantula and of fruit production. In order to better understand the tomato response when grown under drought conditions, field and greenhouse trials were combined with molecular analyses, and various genetic resources were explored. Among these, some wild species and some local ecotypes were chosen, where a wide genetic variability could be still exploited.

\section{Materials and Methods}

\subsection{Plant Material}

Twenty-seven tomato genotypes (Table 1), including

Table 1. List of the 27 tomato genotypes analyzed. For each genotype, the species in the genus Solanum, the category (wild or cultivated), the country of origin and the source providing seeds are reported.

\begin{tabular}{|c|c|c|c|c|}
\hline ACCESSION/NAME & SPECIES & CATEGORY & COUNTRY OF ORIGIN & SOURCE \\
\hline AD17 & S. lycopersicum & advanced line & Italy & Univ. of Naples \\
\hline AL-22/041 & S. lycopersicum & ecotype & Albany & Univ. of Bari \\
\hline $\mathrm{AL}-22 / 044$ & S. lycopersicum & ecotype & Albany & Univ. of Bari \\
\hline AL-22/046 & S. lycopersicum & ecotype & Albany & Univ. of Bari \\
\hline AL-22/057 & S. lycopersicum & ecotype & Albany & Univ. of Bari \\
\hline AL-22/059 & S. lycopersicum & ecotype & Albany & Univ. of Bari \\
\hline AL-22/064 & S. lycopersicum & ecotype & Albany & Univ. of Bari \\
\hline AL-22/070 & S. lycopersicum & ecotype & Albany & Univ. of Bari \\
\hline AL-22/076 & S. lycopersicum & ecotype & Albany & Univ. of Bari \\
\hline Casarbore & S. lycopersicum & ecotype & Italy & Univ. of Naples \\
\hline Chile & S. lycopersicum & cultivar & Chile & Chilean market \\
\hline GiaGiù & S. lycopersicum & ecotype & Italy & Univ. of Naples \\
\hline IL9-2-5 & S. pennellii in S. lycopersicum & introgression line & Israel & TGRC \\
\hline IT-22/005 & S. lycopersicum & ecotype & Italy & Univ. of Bari \\
\hline IT-22/025 & S. lycopersicum & ecotype & Italy & Univ. of Bari \\
\hline IT-22/030-13 & S. lycopersicum & ecotype & Italy & Univ. of Bari \\
\hline LA0462 & S. peruvianum & wild species & Chile & TGRC \\
\hline LA0716 & S. pennellii & wild species & Perù & TGRC \\
\hline LA1421 & S. lycopersicum var. cerasiforme & wild species & Ecuador & TGRC \\
\hline LA1579 & S. pimpinellifolium & wild species & Perù & TGRC \\
\hline LA1959 & S. chilense & wild species & Perù & TGRC \\
\hline LA2711 & S. lycopersicum cv Edkawi & old cultivar & Egypt & TGRC \\
\hline M82 & S. lycopersicum & cultivar & USA & TGRC \\
\hline Parminatella & S. lycopersicum & ecotype & Italy & Univ. of Naples \\
\hline Sel6 & S. lycopersicum & ecotype & Italy & Univ. of Naples \\
\hline Siccagno & S. lycopersicum & ecotype & Italy & Univ. of Naples \\
\hline Vesuvio2001 & S. lycopersicum & ecotype & Italy & Univ. of Naples \\
\hline
\end{tabular}


wild species, ecotypes and varieties, were selected for physiological and molecular analyses. Among the wild species, S. pennellii (LA0716), S. pimpinellifolium (LA1579), S. chilense (LA1972), S. peruvianum (LA0462) and S. lycopersicum var. cerasiforme (LA1421) were obtained from the Tomato Genetic Resource Center (TGRC), together with the old cultivar S. lycopersicum cv. Edkawi (LA2711). Seventeen local ecotypes come from South Italy and Albany; some were kindly provided by Prof. Ricciardi, University of Bari, Italy. In addition, two cultivars (Chile, M82), one advanced selected line (AD17) and one $S$. pennellii introgression line (IL9-2-5) were added to our collection. Seeds were sown directly in the alveolar plateau containing a mixture of soil and peat, seedlings were then transplanted into larger pots about two weeks after sowing and were grown in greenhouse. Seeds that showed a reduced germination rate were pre-germinated in Petri dishes by a solution of $\mathrm{KNO}_{3}(2 \mathrm{~g} / \mathrm{l})$ or $\mathrm{GA}_{3}(3000 \mathrm{ppm})$.

\subsection{Desiccation Test}

Tomato plants were subject to a short desiccation test and both Water Loss Rate (WLR) and Relative Water Content $(R W C)$ were evaluated. Seedlings having similar leaf size and number (at least four true leaves) were selected within each genotype and detached for assaying WLR and $R W C$. As for treated plants, fresh weight $(F W)$ was immediately recorded (time 0 ), and then seedlings were placed on dry paper for $24 \mathrm{~h}$ at room temperature and the weight $\left(W_{24}\right)$ was measured again. After, leaves were soaked in distilled water for $24 \mathrm{~h}$ at room temperature in darkness and the turgid weight (TW) was recorded. Finally, total dry weight $(D W)$ was recorded after drying for $24 \mathrm{~h}$ at $80^{\circ} \mathrm{C}$. As for control plants, only the fresh weight $(F W)$ at time 0 , the turgid weight $(T W)$ and the dry weight $(D W)$ were recorded. In both cases, WLR and $R W C$ were evaluated. The water loss rate $(W L R)$ was measured as described by [14] using the formula:

$$
W L R\left(\mathrm{~g} \cdot \mathrm{h}^{-1} \mathrm{~g}^{-1} D W\right)=\left(F W-W_{24}\right) /(D W \times 24) .
$$

The RWC was calculated according to [15]:

$$
R W C(\%)=[(F W-D W) /(T W-D W)] \times 100 .
$$

\subsection{Field Trial}

Eight tomato cultivars were utilized for a drought test in field conditions (Acerra, Campania region in the Southern Italy). Control and stressed plants were grown under a plastic tunnel under standard agricultural practices and the same watering volume was applied until $50 \%$ of plants appeared to develop fruit set on the first inflorescences. After this time the tested plants were not watered anymore. RWC of control and stressed plants was evalu- ated weekly. Leaf tissues of three plants per genotype were harvested from control and stressed plants for five consecutive weeks after treatment, frozen in liquid nitrogen, and stored at $-80^{\circ} \mathrm{C}$ for RNA extraction. Marketable and scrap fruit harvested from all the genotypes were recorded. The analysis of variance (ANOVA) was carried out using the SPSS (Statistical Package for Social Sciences) Package 6 version 15.0. In particular, the General Linear Model (UNIVARIATE ANOVA with a Duncan Post-Hoc test, $\mathrm{P}<0.05)$ was used to ascertain the differences among genotypes and between stressed and not stressed plants.

\subsection{DNA Sequencing}

Leaf samples were collected from seedlings, frozen in liquid nitrogen and stored at $-80^{\circ} \mathrm{C}$. DNA extraction was performed using the commercial kit DNeasy ${ }^{\circledR}$ Plant Mini Kit provided by QIAGEN following manufacturer's instructions. DNA quality and quantity was checked by agarose electrophoresis and by spectrophotometric quantification utilizing NanoDrop 1000 Spectrophotometer v 3.60. DNA amplification was carried out by PCR using specific primers designed on the gene sequences deposited in GenBank (http://www.ncbi.nlm.nih.gov/nuccore) and/or available at the Solgenomics website

(http://solgenomics.net). PCR products were purified by the QIAquick PCR Purification Kit of QIAGEN. DNA fragments were then sequenced using the BigDye ${ }^{\circledR}$ Terminator Cycle Sequencing Kit v.3.1 based on the Sanger method. Samples were purified using BigDye ${ }^{\circledR}$ XTerminator TM Purification Kit Applied Biosystems and analyzed on a capillary sequencer ABI PRISM 3130 Genetic Analyzer.

\subsection{RNA Analysis}

Total RNA was isolated from homogenized powdered tomato leaves stored at $-80^{\circ} \mathrm{C}$ utilizing the TRI Reagent Solution Ambion with some modifications. Approximately, $0.14 \mathrm{~g}$ of ground leaves were added to $1 \mathrm{ml} \mathrm{TRI}$ Reagent Solution, tubes were shaken and incubated for 5 min at room temp. $200 \mu \mathrm{l}$ of chloroform were added and samples were incubated on ice for $10 \mathrm{~min}$, and then centrifuged at 13,000 $\mathrm{rpm}\left(15 \mathrm{~min}, 4^{\circ} \mathrm{C}\right)$. The aqueous phase was transferred to a clean tube, the nucleic acid was precipitated in the aqueous phase with the addition of $500 \mu \mathrm{l}$ of isopropanol per $1 \mathrm{ml}$ of TRI Reagent solution, vortexed for 5 - $10 \mathrm{sec}$, and incubated on ice for 5 - $10 \mathrm{~min}$. Following centrifugation at $13,000 \mathrm{rpm}\left(15 \mathrm{~min}, 4^{\circ} \mathrm{C}\right)$ the pellet was washed in $1 \mathrm{ml}$ of $75 \%$ ethanol. The samples were then re-dissolved in $300 \mu$ of RNase-free water. RNA samples were quantified finally using a NanoDrop 1000 Spectrophotometer $v 3.60$ and stored at $-80^{\circ} \mathrm{C} .1 \mu \mathrm{g}$ of total RNA was reverse transcribed with the Transcrip- 
tor High Fidelity cDNA Synthesis Kit, Roche. Amplification of Real-TimePCR products was carried out with a 7900HT Fast Real-Time PCR System (Applied Biosystems) using Power SYBR ${ }^{\circledR}$ Green Master Mix (Applied Biosystems) as detection system in a reaction mixture of $25 \mu \mathrm{l}$ containing: $0.5 \mu \mathrm{M}$ of each primer, $12.5 \mu \mathrm{l}$ of SYBR GreenPCR master mix. Preparation of reactions was automated using the liquid handler Freedom Evo 150 (Tecan). Relative quantification was achieved by the $\Delta \Delta \mathrm{Ct}$ method [16].

\subsection{Bioinformatic Tools}

PCR primers were designed using Primer3 Plus software (http://www.bioinformatics.nl/cgi-bin/primer3plus/prime r3plus.cgi/). Sequences for RT-qPCR primers were retrieved from the Universal Probe Library Assay Design Center (http://www.roche-applied-science.com) if available, or alternatively designed ad hoc by using Primer express software version 3.0 (Applied Biosystems). Sequences were processed by ABI PRISM SeqScape software.

\section{Results and Discussion}

In order to gain a deeper understanding of drought response mechanisms in tomato, a collection of 27 tomato genotypes was studied under different water deficit conditions. The collection included five wild species and 17 local ecotypes. In particular, the wild species were selected by exploring the Tomato Genetic Resource Center (TGRC) database (http://tgrc.ucdavis.edu) using the "abiotic stress tolerance" key-word. These species evolved in extreme habitats of South America, where is the tomato origin center. As for the local ecotypes, they were mainly selected both for fruit yield and quality in southern areas of Italy and Albany.

\subsection{Desiccation Test}

The effect of drought during plant growth was evaluated by performing a Short-Term (ST) desiccation test on young plantlet, where the Relative Water Content (RWC) and Water Loss Rate (WLR) were recorded. Indeed, the Relative Water Content is considered as a measure of plant water status showing the metabolic activity in the leaf tissue [17], since the plant resistance/tolerance to drought is related to its ability to maintain higher relative water content in the leaves under water stress. In addition, the WLR could allow the selection of more tolerant genotypes, as also reported in wild barley and wheat where a preliminary screening of genotypes with different response to water deficit was realized on the basis of WLR values $[14,18]$.

For all genotypes analyzed, the RWC values (Figure 1) showed a significant reduction after 24 hours of desicca- tion and no differences were observed within genotypes belonging to the two groups considered (the first including wild genotypes coming from South America and the second mainly ecotypes from South Italy and Albania). In particular, in the first group no significant difference $(\mathrm{P}=0.271)$ was detected for RWC values among well-irrigated plants. In addition, all genotypes showed a significant $(\mathrm{P}=0.001)$ reduction in their RWC 24 hours after the dehydration treatment was applied and also a different response to water stress. Unfortunately, among wild species S. pennellii plants did not produce enough leaves for the RWC test because of their low growing rate; therefore, the leaves collected only allowed performing the molecular analysis. Within the second group of genotypes, significant differences in the RWC values were found both before and after 24 hours of dehydration treatment $(\mathrm{P}<0.001)$.

The values of WLR were variable among tested genotypes and ranged from 0.09 to $0.18 \mathrm{~g} \cdot \mathrm{h}^{-1} \mathrm{~g}^{-1} \mathrm{DW}$ in the first group of genotypes. Univariate ANOVA displayed significant differences among genotypes $(\mathrm{P}<0.001)$. In particular, S. pimpinellifolium and S. lycopersicum cv. Edkawi showed a lower value compared to $S$. lycopersicum var. cerasiforme, which showed the highest value. The ANOVA also showed significant differences among genotypes of the second group $(\mathrm{P}<0.05)$. The values were variable among genotypes and ranged from 0.06 to $0.13 \mathrm{~g} \cdot \mathrm{h}^{-1} \mathrm{~g}^{-1} \mathrm{DW}$; AL-22/057 and M82 showed the lowest values whereas Parminatella showed the highest.

Based on WLR results, tomato genotypes could be roughly classified in susceptible and tolerant as well as done in wild barley and wheat $[14,18]$. Accordingly, most of the genotypes belonging to the second group (AL22/041, AL22/044, AL22/046, AL22/059, AL22/076, IL9-2-5, IT-22/005, IT-22/025, Parminatella, Sel6) were classified as more susceptible, since they had a high WLR after 24 hours of desiccation on the laboratory bench. By contrast, AL22/057, GiaGiù, IT-22/30-013, M82, Siccagno and Vesuvio 2001 showed the lowest values of WLR. Indeed, it is known that the ecotype Siccagno performs better under reduced water supply and the genotype M82 is considered semi tolerant [19]. Therefore, the two genotypes M82 and Siccagno confirmed their tolerance to water deficit, whereas this behavior is new for Vesuvio 2001 and for GiaGiù, which also showed a low WLR value. It is noteworthy that both genotypes come from the same geographical area, which is from Vesuvio slopes.

\subsection{Field Trial}

In order to evaluate the response to drought in terms of yield, a group of local ecotypes was also tested in a field trial, whereas the wild species were excluded since they usually have fruit size very different from the cultivated 


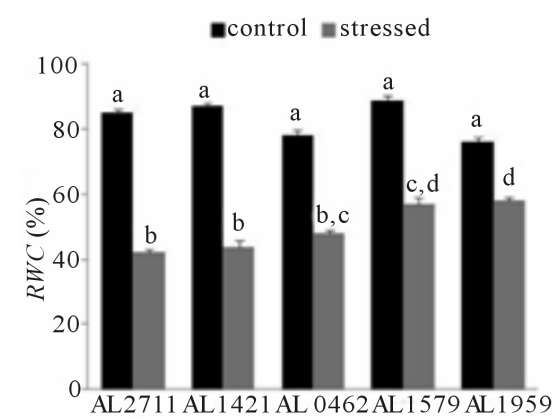

(a)

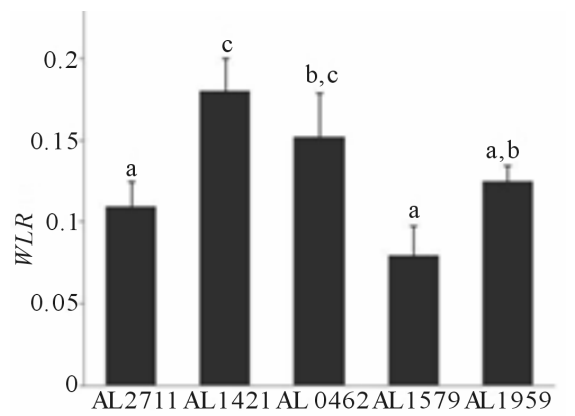

(b)

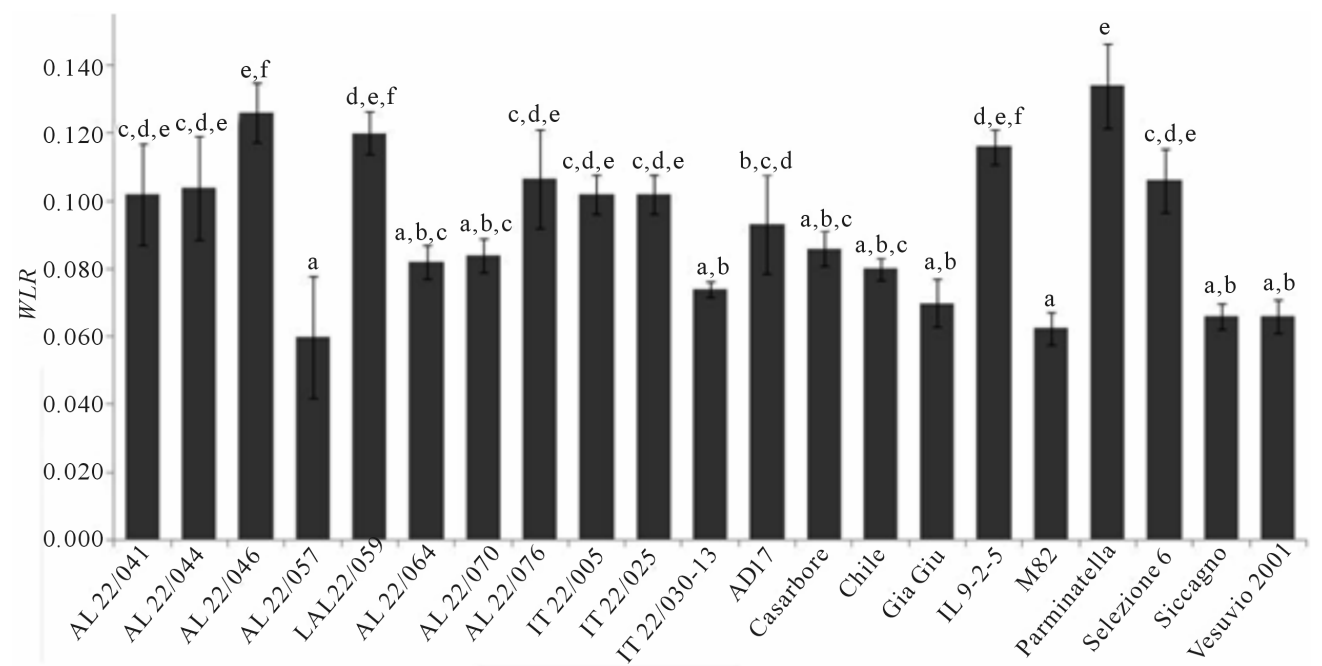

(c)

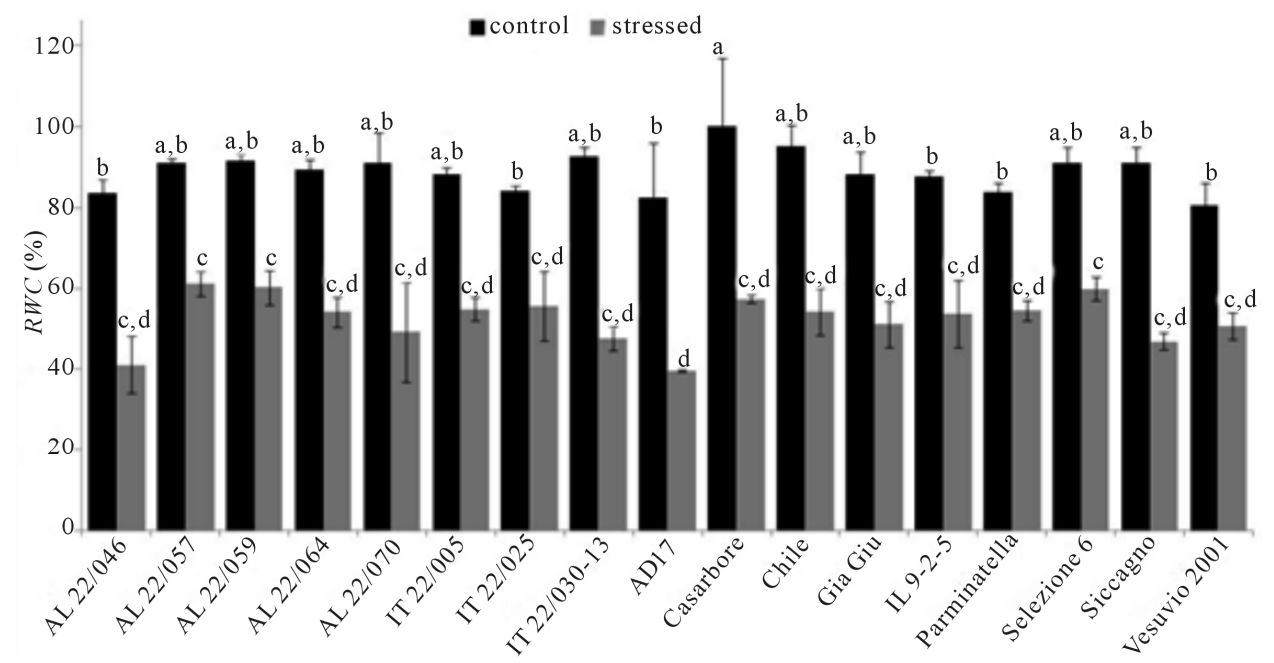

(d)

Figure 1. Relative Water Content (RWC) and Water Loss Rate (WLR) of wild tomato species ((a), (b)), ecotypes and cultivar ((c), (d)) measured after a short term desiccation test. Same letter indicates not significant difference among genotypes (Post Hoc test; Duncan $P<0.05)$.

genotypes and also reduced yield, not comparable with those of ecotypes and varieties. The experiment was carried out with eight genotypes (Casarbore, GiaGiù, Siccagno, AL-22/057, AL-22/059, IT-22/005, IT-22/030-13, IT-22/025) chosen on the basis of previously field data (data not shown) and of the desiccation test carried out in the present work. Indeed, the rapid screening of a high number of genotypes carried out by the laboratory test allowed to select a restricted number of genotypes to submit to the field trial. In particular, the desiccation test 
led to choose four more tolerant genotypes (GiaGiù, Siccagno, AL-22/057, IT-22/030-13), three susceptible (AL-22/059, IT-22/005 and IT-22/025) and one exhibiting an intermediate performance (Casarbore).

The RWC was recorded in consecutive weeks. Overall, most of genotypes did not respond to water deprivation since they did not show any significant decrease in leaf RWC. AL-22/059, IT-22/005 and Siccagno responded early showing a significant reduction in RWC under un-watered conditions limited to the first week whereas IT-22/025 and Casarbore performed a later response.

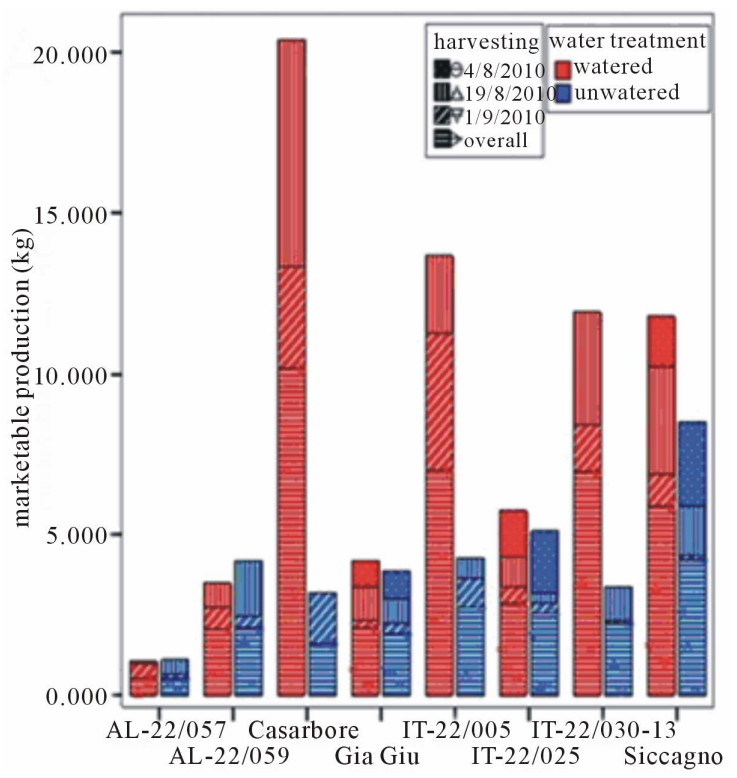

(a)

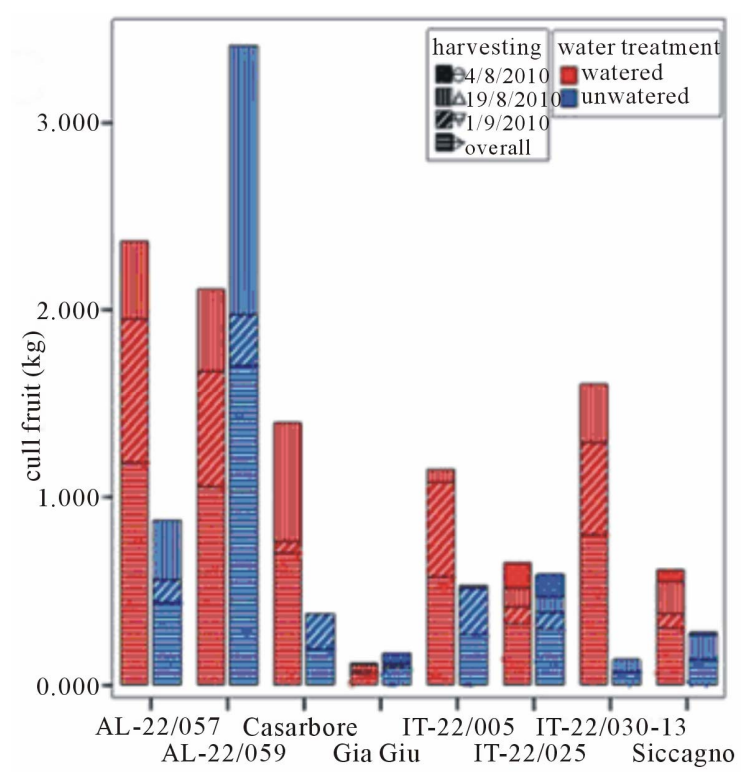

(c)
Red-ripe fruits were harvested from both watered and un-watered plants on August $4^{\text {th }}, 19^{\text {th }}$ and on September $1^{\text {st }}$ and yield parameters were recorded on each harvesting (Figure 2). Overall, Casarbore, IT-22/005, IT-22/ 030-13 and Siccagno showed the highest marketable production when grown in watered conditions. Unfortunately, as often reported for tomato grown in stressful conditions [20], they also showed the strongest decrease under water deprivation, except than Siccagno. Indeed, without water supply Siccagno performed better than the other genotypes. As for the level of marketable produc-

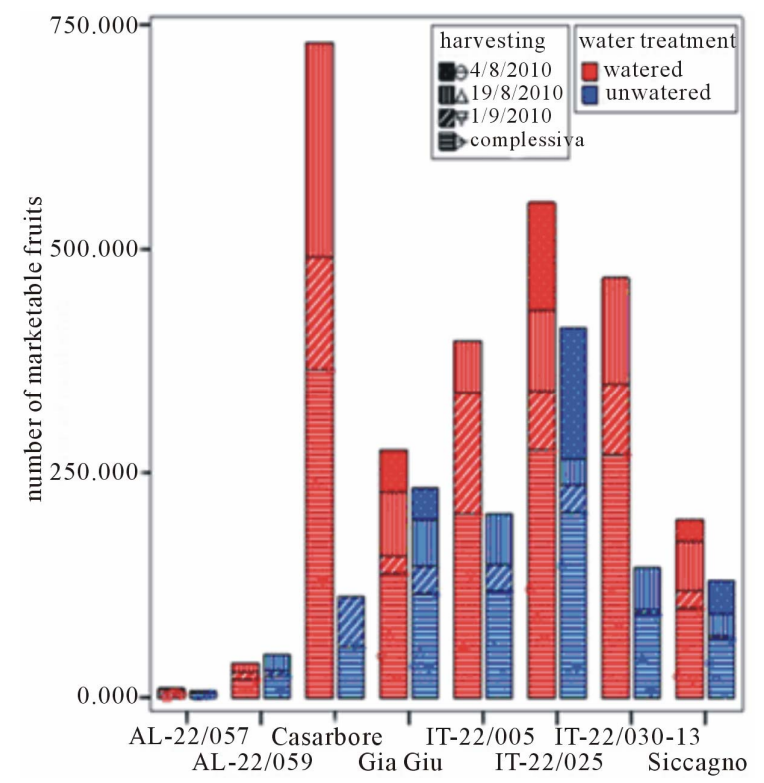

(b)

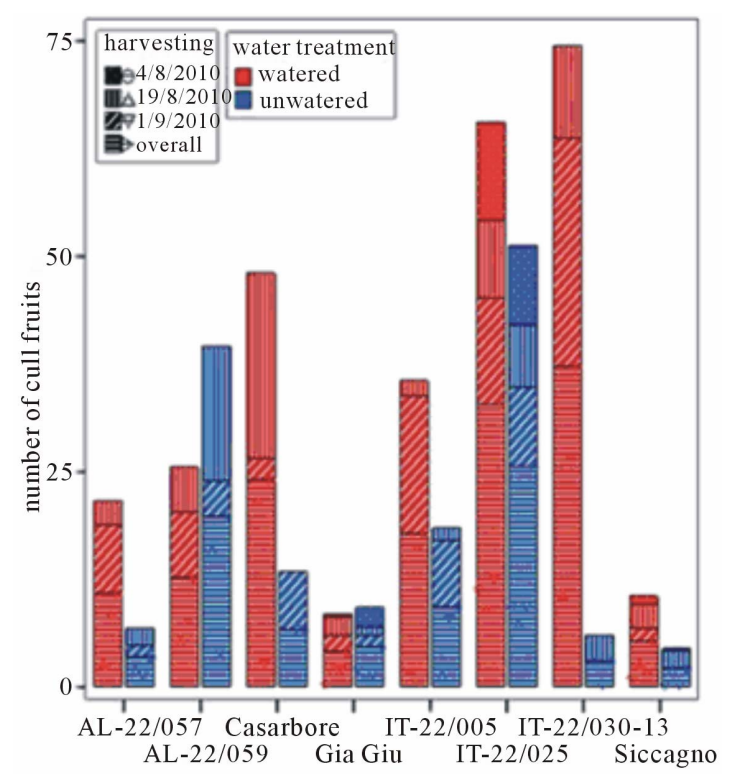

(d)

Figure 2. Yield descriptors (marketable production, number of marketable fruits, cull fruit and number of cull fruits) of tested tomato genotypes in the field trial as recorded according to water treatments and harvest period. (a) Marketable production (Kg); (b) Number of marketable fruits; (c) Cull fruit (Kg); (d) Number of cull fruits. 
tion per plant is concerning, AL-22/057 and AL-22/059 showed an extremely low yield in both watered and un-watered conditions, whereas Casarbore, IT-22/005, IT-22/030-13 confirmed a very deep decrease following un-watering. Finally, GiàGiù, was almost unaffected by water deprivation and Siccagno accounted for a reduced decrease.

Also, the cull fruit per plant both in term of weight and number decreased in the un-watered treatment in all genotypes except than for AL-22/059, which showed an opposite trend (Figure 2). In addition, the reduced water availability affected the average fruit weight of AL-22/ 059 and AL-22/057 showing the highest decrease when water deprivation occurred.

Comprehensively, all tested genotypes were graphically discriminated (Figure 3), according to the water treatment, by Principle Component Analysis (PCA) performed on yield descriptors (marketable production, number of marketable fruits, cull fruit and number of cull fruits, average fruit weight). Two factors explained $84 \%$ of the overall variability. In particular, factor 1 mainly described marketable production and fruits, whereas factor 2 mainly described cull fruit and average fruit weight. A drought-tolerant genotype is expected to gain higher score on factor 1 and lower score on factor 2 regardless of water deprivation. Given this, IT-22/025 and Siccagno ranked best for their ability to grow and produce in low-water input systems. As a whole, the only genotype that showed good performances both in the desiccation test and in the field trial was Siccagno.

\subsection{Polymorphisms in Stress Responsive Genes}

All the genotypes were analyzed at molecular level with the aim of detecting structural polymorphisms in some selected stress responsive genes (Table 2). The sequences of six stress responsive genes, which were previously studied in tomato response to different abiotic stresses, were obtained from the Heinz 1706 complete tomato genome sequence available at the Solgenomics website (www.solgenomics.net). In particular, a BLAST search allowed the identification of the corresponding gene model (identified by mean of a Solyc ID) for ars2, mkp1 and cip1, whereas for the remaining three genes (tsw12, tas14, erd15) only the corresponding scaffold was found. Afterwards, these genes were completely resequenced in the selected collection of 27 genotypes and polymorphisms were fully characterized. Table 3 reports primer sequences designed for the amplification of each gene, the annealing temperature used and the size of the amplified fragment. The resulting sequences were processed by ABI PRISM SeqScape software that allows the analysis of re-sequencing data by comparing consensus

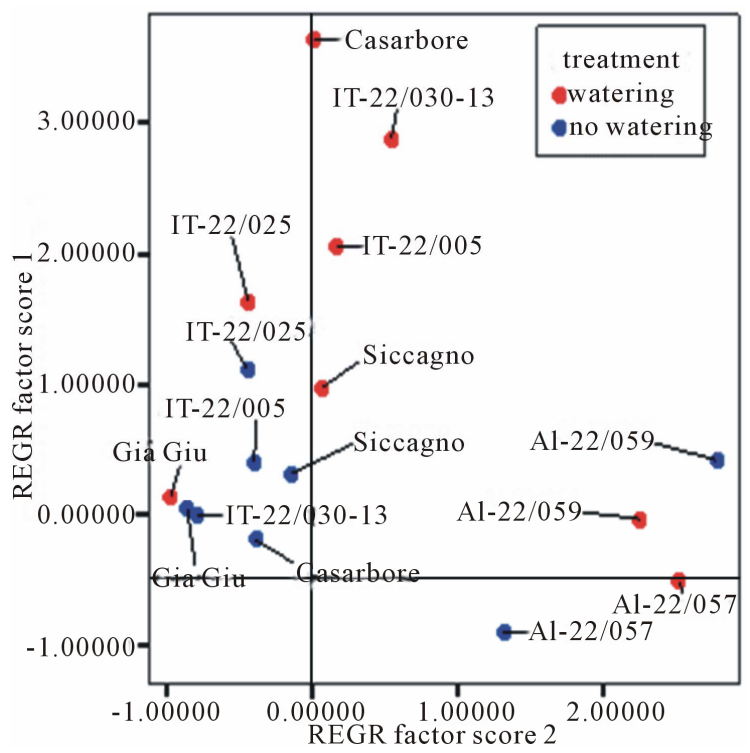

Figure 3. Graphical discrimination of tomato genotypes grown under two water management systems performed by Principle Component Analysis (PCA) based on yield descriptors. Factor 1 and 2 included $84 \%$ of the overall variability. In particular, factor 1 mainly described marketable production, number of marketable fruits, number of cull fruits, whereas factor 2 mainly described cull fruit and average fruit weight.

Table 2. Characteristics of six sequenced genes potentially involved in stress response. For each gene, the gene or scaffold ID of ITAG2.3 annotation in the Solgenomics databases, the chromosome mapping and the length in bp are also reported.

\begin{tabular}{|c|c|c|c|c|c|}
\hline NAME & $\begin{array}{l}\text { ITAG2.3 GENE } \\
\text { /SCAFFOLD ID }\end{array}$ & $\begin{array}{c}\text { GENE } \\
\text { LENGTH (bp) }\end{array}$ & DESCRIPTION & FUNCTIONAL CLASS & REFERENCE \\
\hline$m k p 1$ & Solyc05g054700 ch5 & 3605 & MAP kinase phosphatase & Signal transduction & {$[21,22]$} \\
\hline asr2 & Solyc04g071580 ch4 & 811 & abscicic acid stress ripening 2 & Transcription factor & {$[23,24]$} \\
\hline $\operatorname{tas} 14$ & SL2.40sc03665 ch2 & 746 & $\begin{array}{l}\text { abscisic acid and environmental } \\
\text { stress-inducible protein }\end{array}$ & $\begin{array}{l}\text { Protein response and } \\
\text { damage repair }\end{array}$ & {$[25,26]$} \\
\hline erd 15 & SL2.40sc04199 ch10 & 974 & dehydratation induced protein & Defense protein & {$[29,30]$} \\
\hline $\operatorname{cip} 1$ & Solyc06g073180 ch6 & 3344 & $\begin{array}{l}\text { zinc-finger protein CONSTANS } \\
\text { interacting protein } 1\end{array}$ & $\begin{array}{l}\text { DNA synthesis, cell growth } \\
\text { and division }\end{array}$ & {$[31]$} \\
\hline
\end{tabular}


Table 3. Sequence of forward $(F)$ and reverse $(R)$ primers used to amplify and sequence the different exons of six stress-responsive genes. The annealing temperature (Ta) and the amplified fragment size (bp) are also reported.

\begin{tabular}{|c|c|c|c|c|}
\hline GENE & PRIMER SEQUENCE (5'-3') & $\operatorname{Ta}\left({ }^{\circ} \mathrm{C}\right)$ & FRAGMENT SIZE (bp) & SEQUENCED EXON \\
\hline$m k p 1$ & $\begin{array}{l}\text { F: GGATGCAGTGGCAAGAGATAAGG } \\
\text { R: AACAATCTGGCAAACAGCCCCA }\end{array}$ & 57 & 620 & 1 \\
\hline asr 2 & $\begin{array}{l}\text { F: TGT GTG AAA TGC CAA ACC AT } \\
\text { R: ATC CAA ACG GGC TCA AAG TA A }\end{array}$ & 54 & 991 & $1-2$ \\
\hline tas14 & $\begin{array}{l}\text { F: AGATGGCACAATACGGCAAT } \\
\text { R: TCATTAAACACGGGACACCA }\end{array}$ & 51 & 888 & $1-2$ \\
\hline$t s w 12$ & $\begin{array}{l}\text { F: CAATATGGAAATGGTTAGCAAAA } \\
\text { R: TCGATACAAGACCCCCAAAA }\end{array}$ & 54 & 800 & $1-2$ \\
\hline erd 15 & $\begin{array}{l}\text { F: AATTGGTTTATTAGGCCAGGAAA } \\
\text { R: GTATTTGGGTGGACCAATGG }\end{array}$ & 52 & 880 & $1-2$ \\
\hline cip1I & $\begin{array}{c}\text { F: GTATTTCAAACCCCCACCAA } \\
\text { R: GCTAAAAAGGTAACAAGACACACG }\end{array}$ & 53 & 1222 & 1 \\
\hline $\operatorname{cip} 1 \mathrm{II}$ & $\begin{array}{c}\text { F: TTGTGATGTTCCTTTTGATTAGACTC } \\
\text { R: CTGTGGAGGCATTTTCAAGC }\end{array}$ & 50 & 1382 & 2 \\
\hline cip1III & $\begin{array}{l}\text { F: AAACCAACTGCAGCCACAAC } \\
\text { R: GGCGCTTGGAACATGAAT }\end{array}$ & 50 & 1245 & 3 \\
\hline
\end{tabular}

sequences to a known reference sequence. Identified polymorphisms (SNP or IN/DEL) were characterized for type of variation and localization. Moreover, polymorphisms in the Open Reading Frames (ORF) were analyzed to evaluate their possible effect on the amino acid composition of the corresponding protein. Table 4 reports the number of genotypes exhibiting polymorphisms in the exon regions for all sequenced genes. This varied from a minimum of six genotypes for the gene tas 14 to a maximum of 22 genotypes for the gene asr 2 . As the whole, mutations observed were mainly SNPs (228 out of 236 mutations, $96.2 \%$ ) and only nine INDELs were detected, which cause frameshift in the protein synthesis with respect to that of the reference Heinz 1706. Among the SNPs, 88 (38.6\%) were synonymous mutations, thus not causing amino acid changes in the protein, whereas among the non-synonymous both missesense and nonsense mutations were observed, the latter with a less extent. Table 5 lists the non-synonymous SNPs and the INDELs detected in the six sequenced genes with the consequent amino acid changes. These mutations are described below gene by gene.

Gene mkp1 The gene $m k p 1$ is a member of MAP kinase phosphatases (MKPs), which are potent inactivators of MAP kinases, and are considered important regulators of MAP kinase signaling [21]. In higher plants, MAP kinases are implicated in a multitude of cellular responses to signals such as plant hormones, and both biotic and abiotic stress factors. The mutant $m k p 1$ was studied in A. thaliana and this gene was isolated and sequenced in maize and tomato to examine the evolutionary conservation of its structure [22]. The tomato gene $m k p 1$ is a $3605 \mathrm{bp}$ sequence, including one intron and mapping on the chromosome 5. Since its big size, the sequenced region was restricted to the part of exon 1 carrying the active site motif of the Arabidopsis gene, which is highly conserved in different plant species [22]. Overall, only seven genotypes (Table 4) were polymorphic among the 27 analyzed. A total of 31 mutation events were identified: two were INDELs, 11 were synonymous and 18 were not synonymous. The only wild species exhibiting three non-synonymous SNPs was $S$. peruvianum and the most polymorphic cultivated genotype was AL-22/064 with nine events of mutations that deeply might affect the amino acid sequence (Table 5).

Gene ars2 This gene encodes a putative transcription factor likely involved in one of the signaling pathways of ABA [23] and belongs to the asr gene family (named after abscicic acid [ABA], stress, ripening), exclusively present in plant genomes. The members of this family are up-regulated in roots and leaves of water- or salt-stressed plants. The DNA sequence of asr2 is of $811 \mathrm{bp}$ with two exons (331-489, 602-787) and located on chromosome 4. It has been previously studied in the two wild species $S$. chilense and S. arcanum by an evolutive point of view, since they evolved in habitats with different precipitation regimes [24]. In our collection, almost all genotypes (22 out of 27) revealed polymorphism and a total of $105 \mathrm{mu}-$ tation events were identified, 26 of these were synonymous, 79 not synonymous (Table 4). Unexpected, when compared to the reference genome of Heinz 1706, all genotypes showed the same four consecutive mutations (66 c $>\mathrm{T}, 67 \mathrm{a}>\mathrm{G}, 68 \mathrm{t}>\mathrm{C}, 69 \mathrm{~g}>\mathrm{A}$ ), the first of which was silent whereas the others were missense mutations causing the amino acid change M76A (Table 5). This might imply that a mutation occurred in Heinz 1706 in this genomic region during its evolutive history. Thus, excluding these nucleotide changes, AL-22/046 was the cultivar 
Table 4. Number of polymorphic events detected in the re-sequenced tomato genes among the 27 selected genotypes.

\begin{tabular}{|c|c|c|c|c|}
\hline GENE & PRIMER SEQUENCE (5'-3') & $\operatorname{Ta}\left({ }^{\circ} \mathrm{C}\right)$ & FRAGMENT SIZE (bp) & SEQUENCED EXON \\
\hline$m k p 1$ & $\begin{array}{l}\text { F: GGATGCAGTGGCAAGAGATAAGG } \\
\text { R: AACAATCTGGCAAACAGCCCCA }\end{array}$ & 57 & 620 & 1 \\
\hline asr 2 & $\begin{array}{l}\text { F: TGT GTG AAA TGC CAA ACC AT } \\
\text { R: ATC CAA ACG GGC TCA AAG TA A }\end{array}$ & 54 & 991 & $1-2$ \\
\hline $\operatorname{tas} 14$ & $\begin{array}{l}\text { F: AGATGGCACAATACGGCAAT } \\
\text { R: TCATTAAACACGGGACACCA }\end{array}$ & 51 & 888 & $1-2$ \\
\hline $\operatorname{tsw} 12$ & $\begin{array}{l}\text { F: CAATATGGAAATGGTTAGCAAAA } \\
\text { R: TCGATACAAGACCCCCAAAA }\end{array}$ & 54 & 800 & $1-2$ \\
\hline erd 15 & $\begin{array}{l}\text { F: AATTGGTTTATTAGGCCAGGAAA } \\
\text { R: GTATTTGGGTGGACCAATGG }\end{array}$ & 52 & 880 & $1-2$ \\
\hline $\operatorname{cip} 1 \mathrm{I}$ & $\begin{array}{c}\text { F: GTATTTCAAACCCCCACCAA } \\
\text { R: GCTAAAAAGGTAACAAGACACACG }\end{array}$ & 53 & 1222 & 1 \\
\hline $\operatorname{cip} 1 \mathrm{II}$ & $\begin{array}{l}\text { F: TTGTGATGTTCCTTTTGATTAGACTC } \\
\text { R: CTGTGGAGGCATTTTCAAGC }\end{array}$ & 50 & 1382 & 2 \\
\hline cip1III & $\begin{array}{l}\text { F: AAACCAACTGCAGCCACAAC } \\
\text { R: GGCGCTTGGAACATGAAT }\end{array}$ & 50 & 1245 & 3 \\
\hline
\end{tabular}

with the higher number of mutations even though most of them were heterozygous and thus not stable to be further taken into consideration. AL-22/076 showed a deletion on exon 2 (92 delG), that determines a frameshift in translation. Among wild species, S. peruvianum only showed one missense mutation in exon 1 .

Gene tas14 Tas14 is a dehydrin that accumulates in response to mannitol, $\mathrm{NaCl}$ or abscisic acid (ABA) treatments [25]. The protein encoded by the tas 14 gene is present in various phosphorylated forms and it was found to be localized both in the cytosol and, preferentially, in the nucleus by immunocytochemistry [26]. The genomic sequence is estimated of $746 \mathrm{bp}$ with an intron of $218 \mathrm{bp}$ and the gene maps on chromosome 2: the primers designed amplified both exons (Table 3). Six genotypes exhibited polymorphisms in exons 1 and 2, accounting a total of 48 mutation events (Table 4), but these were non-synonymous SNPs or INDELs only in the two wild species $S$. pennellii and $S$. chilense. In both cases, besides missense mutations, insertions and deletions occurred both in exons 1 and/or 2 (Table 5). In particular, the same nucleotide insertion (109-110insGAGCTGGAG, exon 2) occurred in both species and causes three amino acids GAG in-frame insertion at position 113 of the protein. S. pennellii showed also one additional in frame deletion (130-132delATG, exon 1) and one insertion (177-178insGGAACTCAAGGCATGGGTACTGGT, exon 1). Also, in common between these genotypes a missense base change (144 g > C, exon 2) was observed.

Gene tsw12 The high similarity between the TSW12 deduced amino acid sequence and the reported lipid transfer proteins suggests that $t s w 12$ encodes a lipid transfer protein [27]. tsw 12 mRNA is accumulated during tomato seed germination and its level increases after $\mathrm{NaCl}$ treatment or heat shock. In mature plants, tsw12
mRNA is only detected upon treatment with $\mathrm{NaCl}$, mannitol or ABA and its expression mainly occurs in stems. The $S$. lycopersicum tsw 12 mRNA reported in GenBank (X56040) is 675 bp long. It aligns with a scaffold mapping on chromosome 10, with an estimated genomic sequence length of 893 bp and with the presence of one intron. Nine genotypes (Table 4) were polymorphic and a total of 48 mutation events were identified, 17 of these are synonymous, 28 not synonymous SNPs, and three are INDELs. Noteworthy, in all the cultivated genotypes (Table 5) the presence of different insertions around the position 104 - 106 bp of exon 1 was revealed. Indeed, five genotypes (AD17, AL-22/070, AL-22/076, IT-22/005 and Sel6) showed a deletion ranging from 1 to 4 bases, which in any case causes a frameshift effect. In addition, three wild species (S. peruvianum, S. pennellii and $S$. chilense) showed two substitutions (166 A > G; $167 \mathrm{~A}>$ $\mathrm{G})$ that cause an amino acid change from asparagine to glycine. This result is supported by Trevino and O'Connell [28], who studied the TSW12 protein in S. pennellii.

Gene erd15 The ERD15 (Early Responsive to Dehydration 15) protein is a small, acidic protein with an unknown function and is one of the key negative regulators of ABA responses in plants [29]. The gene erd15 was originally described as a rapidly drought-responsive gene in Arabidopsis [30]. The relative sequence in tomato, estimated to be $974 \mathrm{bp}$ long, is localized on chromosome 10 and presents one intron. Overall, only seven genotypes (Table 4) were polymorphic with a total of $21 \mathrm{mu}-$ tation events, 13 were synonymous while eight were not synonymous. Most SNPs were silent, and common missense SNPs occurred at positions 3, 4 and 6 bp of exon 2 in genotypes AL-22/064, IT-22/005, and S. lycopersicum cv. Edkawi. These SNPs cause an amino acid change from lysine to tyrosine (Table 5). 
Table 5. Type of non-synonymous SNP and INDEL mutations detected in the polymorphic genotypes for the re-sequenced genes. For each mutation event the position of changed nucleotide (nt) and of the related changed amino acid (aa) are reported. Asterisk refers to stop codons.

\begin{tabular}{|c|c|c|c|c|}
\hline GENOTYPE & NT MUTATION & EXON & TYPE OF MUTATION & AA CHANGE \\
\hline \multicolumn{5}{|l|}{ Gene $m k p 1$} \\
\hline \multirow[t]{8}{*}{ AL-22/064 } & $446 \mathrm{t}>\mathrm{A}$ & 1 & Nonsense & $\mathrm{L}_{149}{ }^{*}$ \\
\hline & $447 a>G$ & 1 & Nonsense & L149 ${ }^{*}$ \\
\hline & $448 \mathrm{~g}>\mathrm{T}$ & 1 & Missense & D150C \\
\hline & $449 a>G$ & 1 & Missense & D150C \\
\hline & $450 \mathrm{t}>\mathrm{C}$ & 1 & Missense & D150C \\
\hline & $451 \mathrm{t}>\mathrm{C}$ & 1 & Missense & S151P \\
\hline & 454 del 4 bp & 1 & Frameshift deletion & - \\
\hline & $486 \mathrm{~g}>\mathrm{K}$ & 1 & Missense & $\mathrm{S} 162[\mathrm{R}, \mathrm{L}]$ \\
\hline AL-22/070 & $1 \mathrm{a}>\mathrm{T}$ & 1 & Missense & N1Y \\
\hline \multirow[t]{2}{*}{ IT-22/005 } & $1 \mathrm{a}>\mathrm{T}$ & 1 & Missense & N1Y \\
\hline & 49 delT & 1 & Frameshift deletion & - \\
\hline \multirow[t]{3}{*}{ S. peruvianum } & $134 \mathrm{~g}>\mathrm{A}$ & 1 & Missense & $\mathrm{R} 45 \mathrm{~K}$ \\
\hline & $481 \mathrm{t}>\mathrm{G}$ & 1 & Missense & S161A \\
\hline & $483 \mathrm{a}>\mathrm{T}$ & 1 & Missense & S161A \\
\hline \multicolumn{5}{|l|}{ Gene $a s r 2$} \\
\hline AL-22/046 & $49 \mathrm{a}>\mathrm{Y}$ & 2 & Missense/nonsense & $\mathrm{K} 70\left[\mathrm{Q},{ }^{*}\right]$ \\
\hline AL-22/076 & $92 \mathrm{delG}$ & 2 & Frameshift deletion & - \\
\hline S. peruvianum & $153 \mathrm{~g}>\mathrm{C}$ & 1 & Missense & $\mathrm{L} 51 \mathrm{~F}$ \\
\hline \multicolumn{5}{|l|}{ Gene tas 14} \\
\hline \multirow[t]{6}{*}{ S. pennellii } & $125 \mathrm{~g}>\mathrm{C}$ & 1 & Missense & G24A \\
\hline & 130-132 delATG & 1 & Frameshift deletion & Mdel \\
\hline & 177-178 insGGAACTCAAGCATGGGTACTGGT & 1 & Frameshift insertion & GTQGMGTG59-60ins \\
\hline & $82 \mathrm{~g}>\mathrm{A}$ & 2 & Missense & G105S \\
\hline & 109-110 insGAGCTGGAG & 2 & Frameshift insertion & GAG-113ins \\
\hline & $144 \mathrm{~g}>\mathrm{C}$ & 2 & Missense & $\mathrm{K} 125 \mathrm{~N}$ \\
\hline \multirow[t]{3}{*}{ S. chilense } & $73 c>G$ & 2 & Missense & Q102E \\
\hline & 109-110 insGAGCTGGAG & 2 & Frameshift insertion & GAG-113ins \\
\hline & $144 \mathrm{~g}>\mathrm{S}$ & 2 & Missense & $\mathrm{K} 125[\mathrm{~K}, \mathrm{~N}]$ \\
\hline \multicolumn{5}{|l|}{ Gene $t s w 12$} \\
\hline $\mathrm{ADVF}$ & 104 delC & 1 & Frameshift deletion & - \\
\hline \multirow[t]{5}{*}{ AL-22/070 } & $101 \mathrm{t}>\mathrm{G}$ & 1 & Missense & L34W \\
\hline & $103 \mathrm{~g}>\mathrm{A}$ & 1 & Missense & A35I \\
\hline & $104 \mathrm{c}>\mathrm{T}$ & 1 & Missense & A35I \\
\hline & 105-106 delTC & 1 & Frameshift deletion & - \\
\hline & $108 \mathrm{t}>\mathrm{K}$ & 1 & Missense & $\mathrm{P} 36[\mathrm{~V}, \mathrm{~L}]$ \\
\hline \multirow[t]{2}{*}{ AL-22/076 } & $100 \mathrm{t}>\mathrm{G}$ & 1 & Missense & L34G \\
\hline & $101 \mathrm{t}>\mathrm{G}$ & 1 & Missense & L34G \\
\hline
\end{tabular}




\begin{tabular}{|c|c|c|c|c|}
\hline & 103-106 delGCTC & 1 & Frameshift deletion & - \\
\hline & $108 \mathrm{t}>\mathrm{G}$ & 1 & Missense & P36R \\
\hline \multirow[t]{6}{*}{ IT-22/005 } & $101 \mathrm{t}>\mathrm{G}$ & 1 & Missense & L34W \\
\hline & 105-106 delTC & 1 & Frameshift deletion & - \\
\hline & $107 c>S$ & 1 & Missense & $\mathrm{P} 36[\mathrm{E}, \mathrm{G}]$ \\
\hline & $108 \mathrm{t}>\mathrm{G}$ & 1 & Missense & $\mathrm{P} 36[\mathrm{E}, \mathrm{G}]$ \\
\hline & $109 \mathrm{t}>\mathrm{R}$ & 1 & Missense & $\mathrm{C} 37[\mathrm{P}, \mathrm{A}]$ \\
\hline & $111 \mathrm{c}>\mathrm{S}$ & 1 & Missense & $\mathrm{C} 37[\mathrm{P}, \mathrm{A}]$ \\
\hline Sel6 & 104 delC & 1 & Frameshift deletion & - \\
\hline \multirow[t]{4}{*}{ S. peruvianum } & $154 \mathrm{~g}>\mathrm{A}$ & 1 & Missense & $\mathrm{G} 25 \mathrm{~N}$ \\
\hline & $155 \mathrm{~g}>\mathrm{A}$ & 1 & Missense & $\mathrm{G} 25 \mathrm{~N}$ \\
\hline & $166 a>G$ & 1 & Missense & N56G \\
\hline & $167 a>G$ & 1 & Missense & N56G \\
\hline \multirow[t]{2}{*}{ S. pennellii } & $166 a>G$ & 1 & Missense & N56G \\
\hline & $167 a>G$ & 1 & Missense & N56G \\
\hline \multirow[t]{2}{*}{ S. chilense } & $166 a>R$ & 1 & Missense & $\mathrm{N} 56[\mathrm{~S}, \mathrm{G}]$ \\
\hline & $167 a>G$ & 1 & Missense & $\mathrm{N} 56[\mathrm{~S}, \mathrm{G}]$ \\
\hline \multicolumn{5}{|l|}{ Gene erd 15} \\
\hline \multirow[t]{2}{*}{ AL-22/064 } & $3 t>A$ & 2 & Missense & L114Y \\
\hline & $4 a>C$ & 2 & Missense & L114Y \\
\hline \multirow[t]{3}{*}{ IT-22/005 } & $3 t>A$ & 2 & Missense & L114Y \\
\hline & $4 a>C$ & 2 & Missense & L114Y \\
\hline & $6 c>A$ & 2 & Missense & L114Y \\
\hline \multirow[t]{3}{*}{ S. lycopersicum cv. Edkawi } & $3 t>A$ & 2 & Missense & L114Y \\
\hline & $4 a>C$ & 2 & Missense & L114Y \\
\hline & $6 c>A$ & 2 & Missense & L114Y \\
\hline \multicolumn{5}{|l|}{ Gene cip 1} \\
\hline \multirow[t]{2}{*}{ S. pennellii } & $2296 \mathrm{~g}>\mathrm{R}$ & 2 & Missense & $\mathrm{A} 65[\mathrm{~T}, \mathrm{~A}]$ \\
\hline & $3129 t>C$ & 3 & Missense & S261P \\
\hline
\end{tabular}

Gene cip1 The tomato cip 1 gene is a DNA binding transcription factor involved in response to salt stress, similar to a CONSTANS-like protein studied in $A$. thaliana [31]. It maps to chromosome 6 , has a big size of $3344 \mathrm{bp}$ and presents two introns; therefore three different primer pairs were designed (Table 3), each for sequencing one exon. Overall, only seven genotypes (Table 4) were polymorphic, showing a total of 15 mutation events, 12 were synonymous while three were not synonymous. Among the various mutations, seven SNPs were observed in exon 1 , five occurred in exon 2 and three in exons 3 and 4. Two missense mutations were only observed in S. pennellii (Table 5).
Comprehensively, S. pimpinellifolium, which is the wild species most tolerant at the desiccation test, did not carry any non-synonymous SNPs or INDELs in the sequenced genes. Therefore, no structural variation in the proteins these genes code for could be associated to the tolerance evidenced by this species. In the future, other stress-relative genes might be investigated. On the other side, S. pennellii and S. chilense, whose higher tolerance to drought stress have been previously reported, and confirmed by results of the desiccation test here described, evidenced a common insertion in exon 2 of the gene tas14, which might be related to their tolerance. This polymorphism will be in the future searched for in other 
wild species/accessions exhibiting drought tolerance. Among the cultivated genotypes, particularly interesting are 1) the deletion observed in exon 1 of the gene $t s w 12$ in five genotypes that could be classified as semi-tolerant at the desiccation test, and 2) the missense mutation observed at the beginning of exon 2 of the gene erd15, which was revealed in two tolerant (AL-22/064 and $S$. lycopersicum cv. Edkawi) and one semi-tolerant (IT-22/ 005) genotypes at the desiccation test. All target sequences will be studied in the future in additional species/accessions exhibiting different response to drought.

\subsection{Expression Analysis}

Three water stress-related genes (tas14, tsw12, erd15) analyzed for structural polymorphisms were also studied for their expression level in leaf tissue collected from four non-stressed and stressed genotypes (IT-22/025, IT-22/030-13, GiaGiù and Siccagno) grown in the field trial at Acerra. These genotypes were selected because they exhibited higher tolerance to water deficit as resulted from some of the phenotypic evaluations carried out in this work. The leaf mRNA relative abundance of the mRNA of the three genes was assayed by Real Time $R T-P C R$ (qRT-PCR). In particular, the relative expression, within the specific genotypes, was reported as fold change of the expression in the un-watered plants relatively to the well-watered counterpart. The assay was performed on two different time-points (July $7^{\text {th }}$ and $21^{\text {st }}$ ). As for tas14 and tws 12 (Figure 4), results did not show any significant difference between $7^{\text {th }}$ and $21^{\text {st }}$ of July $(\mathrm{P}$ $>0.05)$. The same trend was observed for the difference

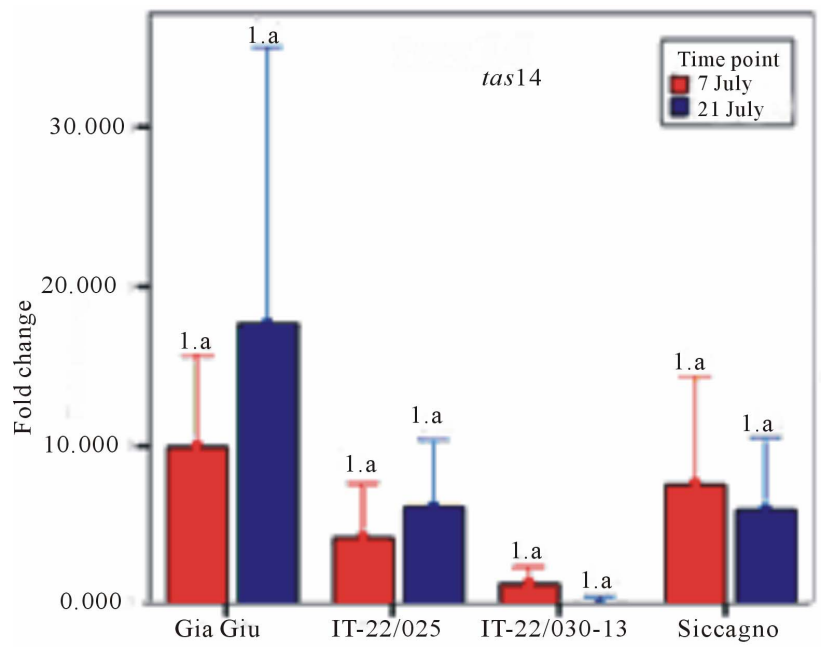

(a)

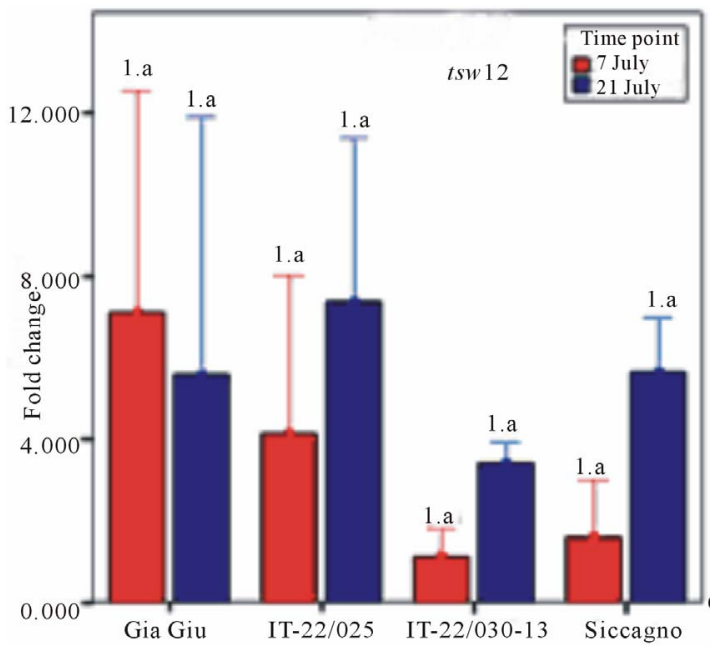

(b)

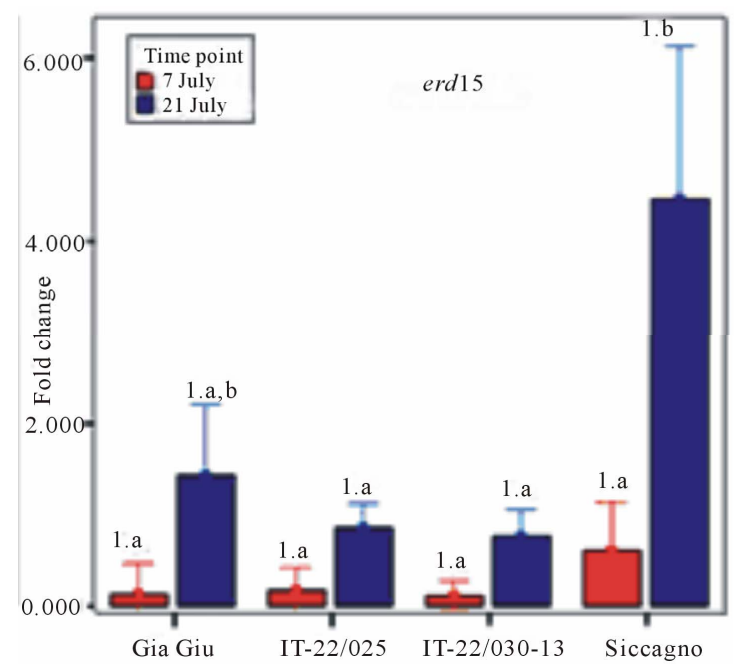

(c)

Figure 4. Leaf relative transcription (fold change) of tas14, tsw12 and erd15 genes in un-watered plants of four tomato genotypes compared to the watered counterpart, as resulting by Real Time qPCR. Same letter indicates not significant differences among genotypes within the same time-point (Post Hoc Test LSD. $P<0.05$ ). Same number indicates not significant differences between time-point within the same genotypes (Post Hoc Test LSD. P < 0.05). 
between the two time points within each genotype $(\mathrm{P}>$ $0.05)$. No significant differences were also observed between genotypes both on July $7^{\text {th }}$ and $21^{\text {st }}$. These results did not allowed to associate differences in the level of expression of tas 14 and tws 12 to the different response of tested genotypes to water deprivation. By contrast, for erd15, an overall significant difference between the two time-points was observed (ANOVA $\mathrm{F}_{1,22}=6.62 ; \mathrm{P}<$ $0.05)$. The same result was not observed within each genotypes $(\mathrm{P}>0.05)$. Significant differences between Siccagno and IT-22/025 as well as between Siccagno and IT-22/030-13 were observed within the July $21^{\text {st }}$ assay (Post Hoc Test LSD; P > 0.05). The latter results allowed arguing a possible implication of higher level of expression of erd 15 in the higher yield stability performed by Siccagno against water deprivation.

To deeper understand the involvement of the sequenced genes in the drought tolerance response, expression data of asr2, tas 14 , tsw 12 , erd 15 and cip 1 were also inferred from a microarray analysis performed comparing the Siccagno genotype under stressed and not stressed conditions (data not shown). As result, we found significant differences among mRNA transcription of tas 14 and erd 15 genes (Table 6). In particular, in Siccagno genotype under stress condition tas 14 gene was down-regulated while erd15 was up-regulated, thus con- firming results obtained by RT-qPCR analysis. Other stress-related genes were searched in the Solgenomics database using "water deprivation" as keyword for the Ontology Term. Among all the genes found in the genome database we selected a group of eight genes, whose expression was assayed in the microarray experiment. Comprehensively, all the genes were down-regulated in the Siccagno genotype under stress conditions with respect to the control. Differences in the expression levels of the genes under study found in the stressed genotype allowed us to strengthen their involvement in the drought tomato response as showed by [7]. However, to completely disclose the molecular mechanisms underlying drought tolerance more studies are required.

\section{Conclusions}

The results reported allowed driving some general conclusions and designing perspectives for future research activities aimed to dissect the complex genetic control of drought tolerance in tomato. Either exploitable genetic resources or molecular information were obtained. Indeed, the ecotype Siccagno ranks among the best for its response to the desiccation test and for its ability to grow and produce in low-water input systems. For other genotypes, as far as the integration of results obtained by dif-

Table 6. List of stress-related genes differentially expressed in un-watered Siccagno genotype respect to the watered control.

\begin{tabular}{|c|c|c|}
\hline GENE & $\begin{array}{c}\text { FOLD CHANGE } \\
\text { STRESSED vs. NOT } \\
\text { STRESSED }\end{array}$ & SL2.3 ITAG ANNOTATION \\
\hline asr2 & -1.133 & Unknown Protein (AHRD V1); contains Interpro domain(s) IPR003496 ABA/WDS induced protein \\
\hline $\operatorname{tas} 14$ & $-2.499^{* * *}$ & Unknown Protein (AHRD V1); contains Interpro domain(s) IPR000167 Dehydrin \\
\hline$t s w 12$ & -1.104 & $\begin{array}{l}\text { Heat shock protein } 4 \text { (AHRD V1 } * * * \text { _ B6U237_MAIZE); contains Interpro domain(s) } \\
\text { IPR013126 Heat shock protein } 70\end{array}$ \\
\hline erd 15 & $0.352^{* *}$ & $\begin{array}{l}\text { ERD15 EARLY RESPONSIVE TO DEHYDRATION } 15 \text { protein binding (AHRD V1 *_*G } \\
\text { AT2G41430.2); contains Interpro domain(s) IPR009818 Ataxin-2, C-terminal }\end{array}$ \\
\hline $\operatorname{cip} 1$ & -0.194 & $\begin{array}{l}\text { Zinc finger protein CONSTANS-LIKE } 1 \text { (AHRD V1 * COL1_ARATH); contains Interpro domain(s) } \\
\text { IPR000315 Zinc finger, B-box }\end{array}$ \\
\hline areb & $-0.820^{* *}$ & $\begin{array}{l}\text { BZIP transcription factor (AHRD V1 } * * * * \text { Q0PN11_9FABA); contains Interpro domain(s) IPR011616 } \\
\text { bZIP transcription factor, bZIP-1 }\end{array}$ \\
\hline bhlh1 & $-2.422^{* * *}$ & $\begin{array}{l}\text { BHLH1 transcription factor (AHRD V1 } * * * * \text { D6BP02_HEVBR); contains Interpro domain(s) } \\
\text { IPR001092Basic helix-loop-helix dimerisation region bHLH }\end{array}$ \\
\hline dreb1 & $-1.400^{* * *}$ & Dehydration responsive element binding protein 1 \\
\hline gras7 & $-1.169^{* *}$ & $\begin{array}{l}\text { GRAS family transcription factor (AHRD V1 } * * * * \text { B9IAQ7_POPTR); contains Interpro domain(s) } \\
\text { IPR005202 GRAS transcription factor }\end{array}$ \\
\hline wrky42 & $-1.103^{* *}$ & $\begin{array}{c}\text { WRKY transcription factor (AHRD V1 } * * * \text { _ D3YEX5_SOLLC); contains Interpro domain(s) IPR003657 } \\
\text { DNA-binding WRKY }\end{array}$ \\
\hline bhlh & -0.554 & $\begin{array}{c}\text { Transcription factor (AHRD V1 *_-* Q9M4A8_MAIZE); contains Interpro domain(s) IPR011598 } \\
\text { Helix-loop-helix DNA-binding }\end{array}$ \\
\hline ap2-like & $-1.125^{* *}$ & AP2-like ethylene-responsive transcription factor \\
\hline bhlh & -0.743 & $\begin{array}{c}\text { Transcription factor (AHRD V1 *_*_ D6MKM4 9ASPA); contains Interpro domain(s) IPR011598 } \\
\text { Helix-loop-helix DNA-binding }\end{array}$ \\
\hline
\end{tabular}

"Statistically significant differences at $\mathrm{P}<0.05 ;{ }^{* *} 0.01<\mathrm{P}<0.05 ;{ }^{* * *} \mathrm{P}<0.01$. 
ferent tests, plant response to water deficit in many cases contrasted when plant growth and fruit production were compared. This might confirm that different mechanisms act in plant response to drought during different developmental stages.

Many polymorphisms were detected in six stress-responsive genes, and some of them could imply significant modifications in the consequent protein structure. The potential involvement of these polymorphisms in a differential response to water deficit should be further investigated. Furthermore, the expression analysis by RT-qPCR of three stress-responsive genes allowed arguing a possible implication of a higher level of expression of gene erd 15 in the higher yield stability performed by Siccagno against water deprivation. Similarly, the lower expression of eight genes in the same genotype analysed through a microarray experiment confirmed the involvement of these stress-related genes in the tomato response to drought.

Nowadays, the availability of highly performing sequencing techniques, such as the various NGS (Next Generation Sequencing) platforms, will allow in the future targeting re-sequencing many stress-responsive gene contemporarily in drought tolerant and sensitive genotypes, in order to associate structural variation to a better response to water deprivation. In addition, these techniques will allow studying the complete transcriptomic response of the genotype Siccagno at different water supplies, in order to identify those genes whose differential expression might be crucial to enhance the tolerance to stress.

\section{Acknowledgements}

This research was supported by the project GenoPOM funded by Miur. The authors thank Prof. Ricciardi from the University of Bari for providing seeds and Dr. Spigno from ARCA2010 for plant growth in the field.

\section{REFERENCES}

[1] T. Umezawa, M. Fujita, Y. Fujita, K. Yamaguchi-Shinozaki and K. Shinozaki, "Engineering Drought Tolerance in Plants: Discovering and Tailoring Genes to Unlock the Future," Current Opinion in Biotechnology, Vol. 17, No. 2, 2006, pp. 113-122. http://dx.doi.org/10.1016/j.copbio.2006.02.002

[2] J. C. Cushman and H. J. Bohnert, "Genomic Approaches to Plant Stress Tolerance," Current Opinion in Plant Biology, Vol. 3, No. 2, 2000, pp. 117-124. http://dx.doi.org/10.1016/S1369-5266(99)00052-7

[3] V. Chinnusamy, K. Schumaker and J. Zhu, "Molecular Genetic Perspectives on Cross-Talk and Specificity in Abiotic Stress Signalling in Plants," Journal of Experimental Botany, Vol. 55, No. 395, 2004, pp. 225-236. http://dx.doi.org/10.1093/jxb/erh005
[4] M. Seki, T. Umezawa, K. Urano and K. Shinozaki, "Regulatory Metabolic Networks in Drought Stress Responses," Current Opinion in Plant Biology, Vol. 10, No. 3, 2007, pp. 296-302. http://dx.doi.org/10.1016/j.pbi.2007.04.014

[5] M. Seki, M. Narusaka, J. Ishida, T. Nanjo, M. Fujita, Y. Oono, A. Kamiya, M. Nakajima, A. Enju, T. Sakurai, M. Satou, K. Akiyama, T. Taji, K. Yamaguchi-Shinozaki, .P. Carninci, J. Kawai, Y. Hayashizaki and K. Shinozaki, "Monitoring the Expression Profiles of 7000 Arabidopsis Genes under Drought, Cold and High-Salinity Stresses Using a Full-Length cDNA Microarray," Plant Journal, Vol. 31, No. 3, 2002, pp. 279-292.

http://dx.doi.org/10.1046/j.1365-313X.2002.01359.x

[6] M. A. Rabbani, K. Maruyama, H. Abe, M. A. Khan, K. Katsura, Y. Ito, K. Yoshiwara, M. Seki, K. Shinozaki and K. Yamaguchi-Shinozaki, "Monitoring Expression Profiles of Rice Genes under Cold, Drought, and High-Salinity Stresses and Abscisic Acid Application Using cDNA Microarray and RNA Gel-Blot Analyses," Plant Physiology, Vol. 133, No. 4, 2003, pp. 1755-1767. http://dx.doi.org/10.1104/pp.103.025742

[7] P. Gong, J. Zhang, H. Li, C. Yang, C. Zhang, X. Zhang, Z. Khurram, Y. Zhang, T. Wang, Z. Fei and Z. Ye, "Transcriptional Profiles of Drought-Responsive Genes in Modulating Transcription Signal Transduction, and Biochemical Pathways in Tomato," Journal of Experimental Botany, Vol. 61, No. 13, 2010, pp. 3563-3575. http://dx.doi.org/10.1093/jxb/erq167

[8] E. A. Bray, "Genes Commonly Regulated by WaterDeficit Stress in Arabidopsis Thaliana," Journal of Experimental Botany, Vol. 55, No. 407, 2004, pp. 23312341. http://dx.doi.org/10.1093/jxb/erh270

[9] M. Seki, M. Satou, T. Sakurai, K. Akiyama, K. Iida, J. Ishida, M. Nakajima, A. Enju, M. Narusaka, M. Fujita, Y. Oono, A. Kamei, K. Yamaguchi-Shinozaki and K. Shinozaki, "RIKEN Arabidopsis Full-Length (RAFL) cDNA and Its Applications for Expression Profiling under Abiotic Stress Conditions," Journal of Experimental Botany, Vol. 55, No. 395, 2004, pp. 213-223. http://dx.doi.org/10.1093/jxb/erh007

[10] R. R. Mir, M. Zaman-Allah, N. Sreenivasulu, R. Trethowan and R. K. Varshney, "Integrated Genomics, Physiology and Breeding Approaches for Improving Drought Tolerance in Crops," Theoretical and Applied Genetics, Vol. 125, No. 4, 2012, pp. 625-645.

http://dx.doi.org/10.1007/s00122-012-1904-9

[11] M. R. Foolad, "Genome Mapping and Molecular Breeding of Tomato," International Journal of Plant Genomics, Vol. 2007, 2007, Article ID: 64358. http://dx.doi.org/10.1155/2007/64358

[12] R. Tuberosa and S. Salvi, "Genomics-Based Approaches to Improve Drought Tolerance of Crops," Trends Plant Science, Vol. 11, No. 8, 2006, pp. 405-412. http://dx.doi.org/10.1016/j.tplants.2006.06.003

[13] The Tomato Genome Consortium, "The Tomato Genome Sequence Provides Insights into Fleshy Fruit Evolution," Nature, Vol. 485, No. 7400, 2012, pp. 635-641. http://dx.doi.org/10.1038/nature11119

[14] T. Suprunova, T. Krugman, T. Fahima, G. Chen, I. Shams, 
A. Korol and E. Nevo, "Differential Expression of Dehydrin Genes in Wild Barley, Hordeum spontaneum, Associated with Resistance to Water Deficit," Plant, Cell \& Environment, Vol. 27, No. 10, 2004, pp. 1297-1308. http://dx.doi.org/10.1111/j.1365-3040.2004.01237.x

[15] H. D. Barrs and P. E. Weatherley, "A Re-Examination of the Relative Turgidity Technique for Estimating Water Deficit in Leaves," Australian Journal of Biological Science, Vol. 15, No. 3, 1962, pp. 413-428.

[16] K. J. Livak and T. D. Schmittgen, "Analysis of Relative Gene Expression Data Using Real-Time Quantitative PCR and the 2- $\Delta \Delta$ CT Method," Methods, Vol. 25, No. 4, 2001, pp. 402-408.

http://dx.doi.org/10.1006/meth.2001.1262

[17] D. J. Flower and M. M. Ludlow, "Contribution of Osmotic Adjustment to the Dehydration Tolerance of Water-Stressed Pigeonpea (Cajanus cajan (L.) millsp.) Leaves," Plant, Cell \& Environment, Vol. 9, No. 1, 1986, pp. 33-40.

[18] P. Rampino, S. Pataleo, C. Gerardi, G. Mita and C. Perrotta, "Drought Stress Response in Wheat: Physiological and Molecular Analysis of Resistant and Sensitive Genotypes," Plant, Cell and Environment, Vol. 29, No. 12, 2006, pp. 2143-2152. http://dx.doi.org/10.1111/j.1365-3040.2006.01588.x

[19] A. Van Deynze, K Stoffel, C. R. Buell, A. Kozik, J. Liu, E. van der Knaap and D. Francis, "Diversity in Conserved Genes in Tomato," BMC Genomics, Vol. 8, 2007, p. 465. http://dx.doi.org/10.1186/1471-2164-8-465

[20] C. Patanè and S. L. Cosentino, "Effects of Soil Water Deficit on Yield and Quality of Processing Tomato under a Mediterranean Climate," Agricultural Water Management, Vol. 97, No. 1, 2010, pp. 131-138. http://dx.doi.org/10.1016/j.agwat.2009.08.021

[21] C. Jonak, W. Ligterink and H. Hirt, "MAP Kinases in Plant Signal Transduction," Cellular and Molecular Life Science, Vol. 45, 1999, pp. 204-213. http://dx.doi.org/10.1007/s000180050285

[22] R. Ulm, E. Revenkova, G. P di Sansebastiano, N. Bechtold and J. Paszkowski, "Mitogen-Activated Protein Kinase Phosphatase Is Required for Genotoxic Stress Relief in Arabidopsis," Genes and Development, Vol. 15, No. 6, 2001, pp. 699-709. http://dx.doi.org/10.1101/gad.192601

[23] R. R. Finkelstein, S. S. L. Gampala and C. D. Rock, "Abscisic Acid Signaling in Seeds and Seedlings," Plant
Cell, Vol. 14, 2002, pp. S15-S45.

[24] M. I. Giombini, N. Frankel N. D. Iusem and E. Hasson, "Nucleotide Polymorphism in the Drought Responsive Gene Asr2 in Wild Populations of Tomato," Genetica, Vol. 136, No. 1, 2009. pp. 13-25. http://dx.doi.org/10.1007/s10709-008-9295-1

[25] M. M. Parra, O. del Pozo, R. Luna, J. A. Godoy and J. A. Pintor-Toro, "Structure of the Dehydrin tas14 Gene of Tomato and Its Developmental and Environmental Regulation in Transgenic Tobacco," Plant Molecular Biology, Vol. 32, No. 3, 1996, pp. 453-460. http://dx.doi.org/10.1007/BF00019097

[26] J. A. Godoy, R. Luna, S. Torres-Schumann, J. Moreno, R. M. Rodrigo and J. A. Pintor-Toro, "Expression, Tissue Distribution and Subcellular Localization of Dehydrin TAS14 in Salt-Stressed Tomato Plants," Plant Molecular Biology, Vol. 26, No. 6, 1994, pp. 1921-1934. http://dx.doi.org/10.1007/BF00019503

[27] S. Torres-Schumann, J. A. Godoy and J. A. Pintor-Toro, "A Probable Lipid Transfer Protein Gene Is Induced by $\mathrm{NaCl}$ in Stems of Tomato Plants," Plant Molecular Biology, Vol. 18, No. 4, 1992, pp. 749-757. http://dx.doi.org/10.1007/BF00020016

[28] M. B. Treviño and M. A. O'Connell, “Three DroughtResponsive Members of the Nonspecific Lipid-Transfer Protein Gene Family in Lycopersicon pennellii Show Different Developmental Patterns of Expression," Plant Physiology, Vol. 116, No. 4, 1998, pp. 1461-1468. http://dx.doi.org/10.1104/pp.116.4.1461

[29] T. Kariola, G. Brader, E. Helenius, J. Li, P. Heino and E. T. Palva, "Early Responsive to Dehydration 15, a Negative Regulator of Abscisic Acid Responses in Arabidopsis," Plant Physiology, Vol. 142, No. 4, 2006, pp. 15591573. http://dx.doi.org/10.1104/pp.106.086223

[30] T. Kiyosue, K. Yamaguchi-Shinozaki and K. Shinozaki, "ERD15, a cDNA for a Dehydration-Induced Gene from Arabidopsis Thaliana," Plant Physiology, Vol. 106, No. 4, 1994, p. 1707. http://dx.doi.org/10.1104/pp.106.4.1707

[31] O. Ben-Naim, R. Eshed, A. Parnis, P. Teper-Bamnolker, A. Shalit, G. Coupland, A. Samach and E. Lifschitz, "The CCAAT Binding Factor Can Mediate Interactions between CONSTANS-Like Proteins and DNA," The Plant Journal, Vol. 46, No. 3, 2006, pp. 462-476. http://dx.doi.org/10.1111/j.1365-313X.2006.02706.x 